\title{
The life-history of basalt ground stone tools from early urban domestic contexts: A chronicle from the EBA III of Tell es-Safi/Gath, Israel
}

\author{
Jeremy A. Beller ${ }^{1}$, Haskel J. Greenfield ${ }^{1}$, Itzhaq Shai ${ }^{2}$, Aren M. Maeir ${ }^{3}$ \\ 1. University of Manitoba, Department of Anthropology and St. Paul's College, Winnipeg MB; R3T 2N2, \\ Canada. Email: beller.jeremy.a@gmail.com; Haskel: Haskel.Greenfield@umanitoba.ca \\ 2. Israel Heritage Department, Ariel University, P.O.B. 3, Ariel 40700 Israel. Email:shai.itzick@gmail.com \\ 3. Bar-Ilan University, Institute of Archaeology, the Martin (Szusz) Department of Land of Israel Studies and \\ Archaeology, Ramat Gan 52900, Israel. Email: arenmaeir@gmail.com
}

\begin{abstract}
:
Recent archaeological excavations at the early urban settlement of Tell es-Safi/Gath, Israel present the opportunity to reconstruct the life-history of basalt ground stone artefacts of an early urban domestic neighbourhood. Tell es-Safi/Gath is a multi-period site located on the border between the Judean foothills and the southern coastal plain of central Israel. Survey and excavations over the last two decades demonstrated that it was a major urban centre for the region during the Early Bronze Age (EBA) III. At the eastern end of the site, a neighbourhood of commoner residences (some perhaps associated with mercantile activities) have been exposed. This paper describes and analyses the basalt ground stone tools found in association with this domestic neighbourhood. It seeks to establish the nature of production, distribution, consumption, and discard associated with ground stone tools within a domestic context. The study involved several forms of analysis including typology, macroscopic observations, and excavation data. It is suggested that basalt sources from the northeastern regions of the southern Levant were exploited for the small-scale production of basalt artefacts by nonspecialised craftsmen. These commodities were then transported in more or less finished form to Tell es-Safi/Gath where they were further redistributed or sold to the settlement residents. The residents of the Tell es-Safi/Gath neighbourhood utilised the basalt artefacts for traditionally domestic tasks, and ultimately intentionally discarded or recycled them in a few depositional contexts. In summary, this paper presents a unique investigation into the life-history of basalt ground stone artefacts discovered in the EB III occupation levels of Tell es-Safi/Gath. It further demonstrates the potential of ground stone tools for understanding the behaviour and daily life of non-elite people.
\end{abstract}

Keywords: Tell es-Safi/Gath; early complex societies; southern Levant; ground stone tools; Early Bronze Age; basalt

\section{Introduction}

Excavations of Tell es-Safi/Gath, Israel (Figure 1) have unearthed portions of an extensive early urban settlement dated to the Early Bronze Age (hereafter EBA) III (ca. 2900-

Published by the School of History, Classics and Archaeology, University of Edinburgh ISSN: 2055-0472. URL: http://journals.ed.ac.uk/lithicstudies/

This work is licensed under a Creative Commons Attribution 2.5 UK: Scotland License. 
2500 BCE). The largest portion of EB remains are located on the lower end of the tell, at the eastern end of the site. In this area, we have excavated a residential neighbourhood composed of approximately four housing structures and intersected by an alleyway (Uziel \& Maeir 2005; Shai et al. 2012; 2014). The material culture from Tell es-Safi/Gath provides an opportunity to investigate issues regarding human behaviour at a large urban centre during the zenith of urbanism and social complexity of the EB southern Levant (de Miroschedji 2006; 2009; Greenberg 2014).

An important element of the material culture associated with domestic residences is the ground stone tool assemblage. The examination of the life-history of ground stone artefacts can enhance our understanding of production, distribution, consumption, and discard behaviour at the site (Wright 2008; Adams 2014a: 4). However, most ground stone analyses appear to focus on one of these life-history stages and fall into one of three broad approaches: 1) a purely typological approach to categorising their function frequently found in site assemblage reports (e.g., Hovers 1996; Rowan 2003; Katz 2012), 2) a tribological approach (e.g., the study of interacting surfaces) to examine their use-wear patterns (e.g., Hamon 2008; Liu et al. 2010; Adams 2014b; Dubreuil \& Savage 2014), or 3) a provenance approach to identify their source of origin and movement (e.g., Philip and Williams-Thorpe 1993; Gluhak \& Rosenberg 2013). As most studies typically involve only one of the above approaches, other aspects of the life-history often remain unexplored. However, when these approaches are applied in tandem, they provide a more comprehensive understanding of the life-history of ground stone artefacts (Wright 2008).

In this paper, we present a case study of the advantages of this broader and more integrated approach. As such, this study attempts to reconstruct the life-history of EB III basalt objects from a domestic neighbourhood of Tell es-Safi/Gath. Among the issues to be examined is whether an increased understanding of the basalt ground stone artefacts found in the neighbourhood will shed light upon the socio-economic formations within and between early urban centres. Each socio-economic stage is investigated by drawing upon the results of several analyses. Each separate analysis provides information on more than one stage. Together, these compose a fuller picture of the life-history of the basalt objects.

\section{Archaeological context}

A brief summary of the EBA III domestic occupation at Tell es-Safi/Gath is presented below (for more extensive descriptions see Shai et al. 2012; 2014). The archaeological site of Tell es-Safi/Gath is located in central Israel (Figure 1), approximately midway between the modern cities of Ashdod and Bet Shemesh, and approximately $25 \mathrm{~km}$ inland from the Mediterranean Sea (Maeir 2012). Located on the border of the shephelah (foothills) and coastal plain, the EBA III settlement of Tell es-Safi/Gath is situated atop a natural Eocene limestone-chalk formation (Ackermann \& Bruins 2012). The local landscape proximate to Tell es-Safi/Gath include arable fields and the Nahal Ha'elah water source, which together with the height of the natural formation provided a strategic and hospitable location for early and long-term residence.

EBA remains at Tell es-Safi/Gath have been discovered across the entire 24 ha extent of the tell (Figure 2) (Uziel \& Maeir 2005; Shai et al. 2014; Greenfield et al. 2015). Excavations have focused on the EBA III remains in Area E on the eastern spur and have exposed a residential neighbourhood comprised of four housing complexes aligned on either side of a narrow alleyway. Although many goods of exotic origins are present, there are very few elite artefacts and no evidence of elite structures among the Area E remains (Shai et al. 2014). The housing complexes form part of a non-elite residential neighbourhood, which has been proposed to possibly represent a merchants’ quarter (Greenfield et al. 2012). 


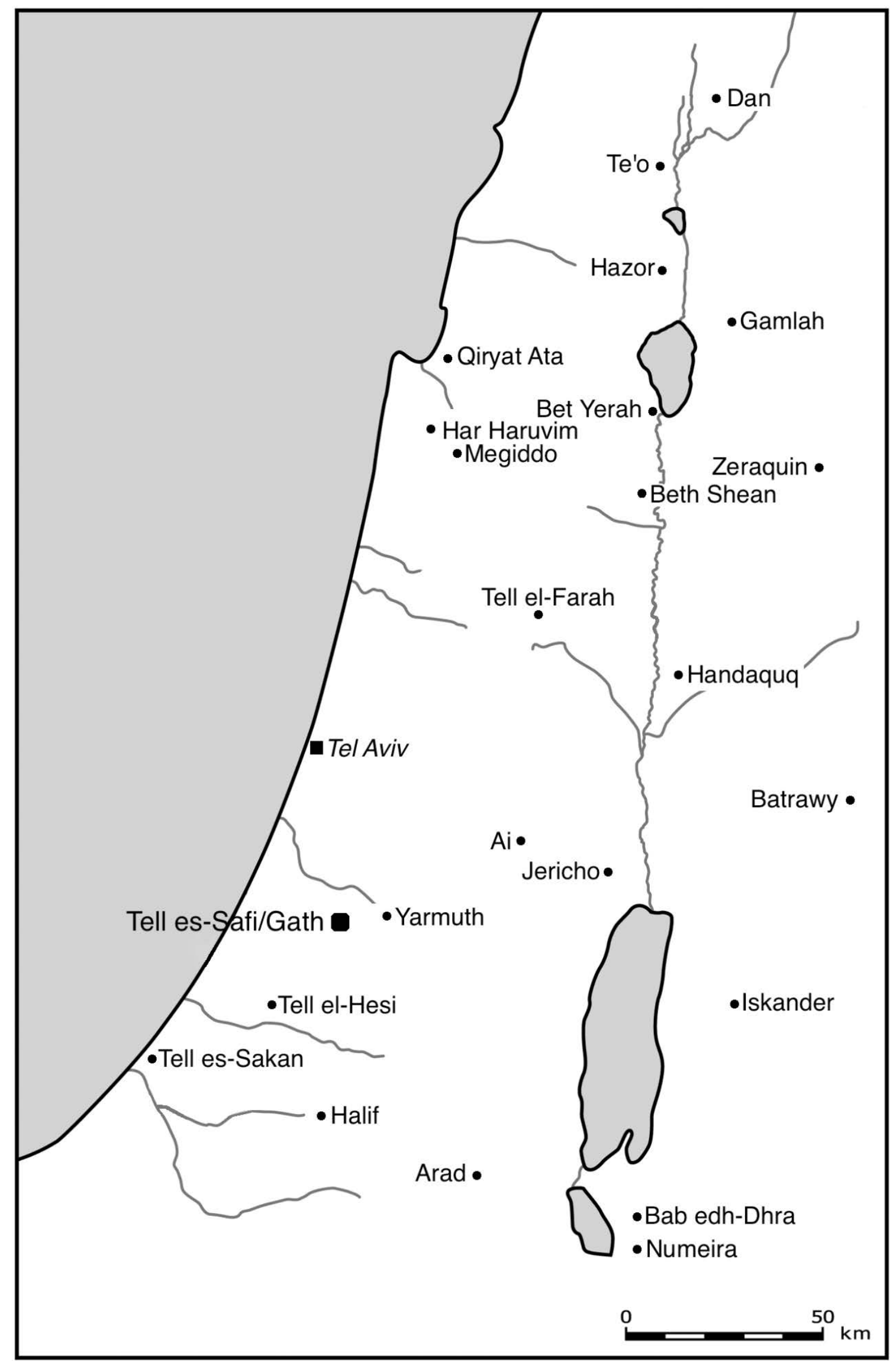

Figure 1. Map of EB II-III southern Levant. 


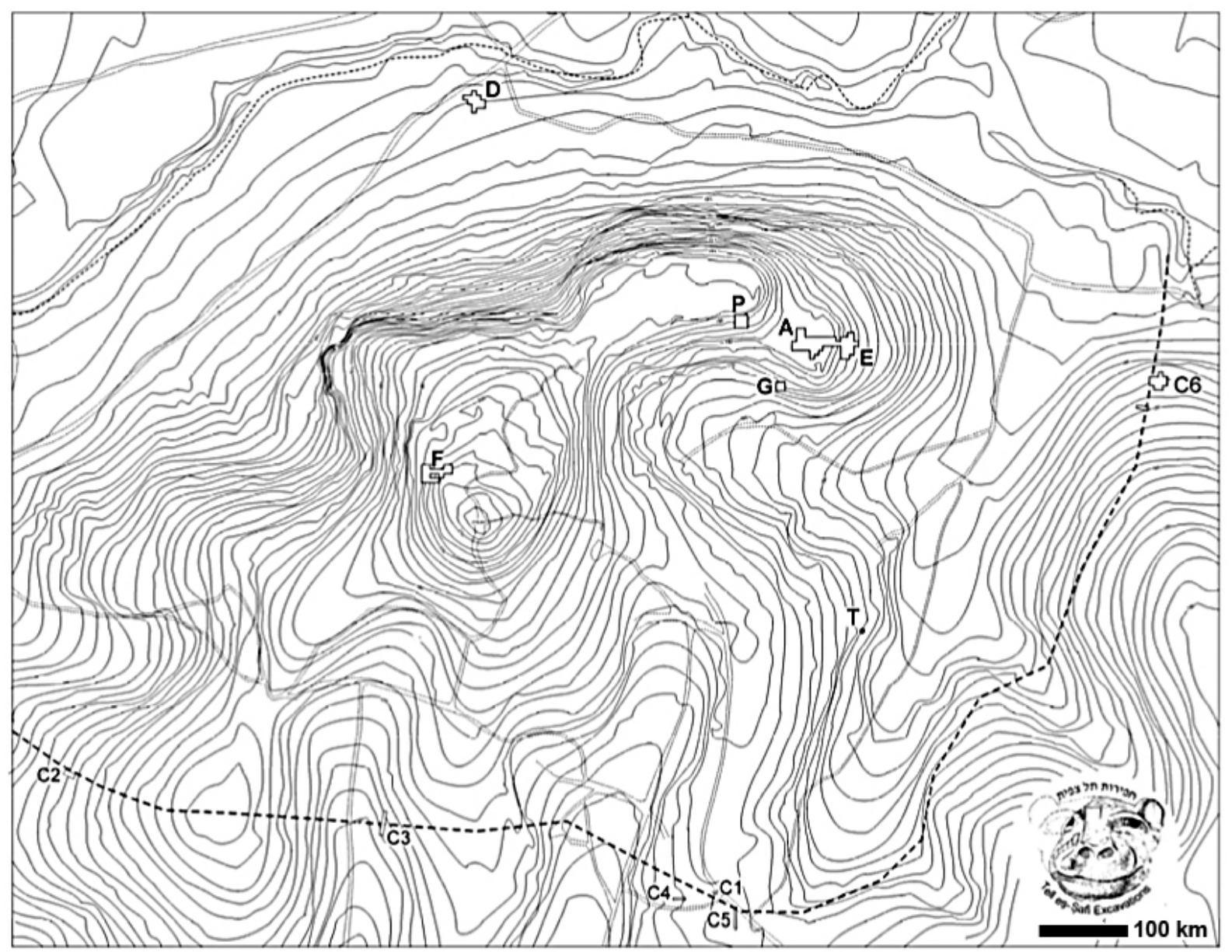

Figure 2. Location of Area E on tell.

At present, three stratigraphic EBA layers have been identified in the Area $\mathrm{E}$ excavations. From latest to earliest, they are Strata E5 (later half of the Early Bronze Age III, henceforth EBA III), E6 (earlier half of EBA III), and E7 (most likely later EBA II). The most extensively excavated of these strata is Stratum E5 $\left(60 \mathrm{~m}^{2}\right)$ with three separate occupational phases (E5a, E5b, and E5c). A much smaller area of the underlying Stratum E6 has been uncovered $\left(20 \mathrm{~m}^{2}\right)$. As Stratum E7 is almost completely unexcavated and poorly understood at this time, the focus of this paper will be on the remains from Strata E5 and E6, the EBA III remains.

\section{Material and methods}

\subsection{Sample size}

The sources of data for this study are the basalt objects of EBA III Tell es-Safi/Gath. This sample is comprised of thirty-two basalt artefacts, of which twenty-nine are grinding stones. The assemblage was recovered during the 2005-2013 field seasons and are now stored at Bar-Ilan University, Israel.

\subsection{Excavation and artefact recovery}

Area $\mathrm{E}$ is being excavated using modern scientific techniques that employ a combination of the stratigraphic and architectural traditions, and systematic recovery of remains through dry sieving and extensive floatation and wet-sieving operations. These separate techniques are practiced in order to collect minute material that would normally go unstudied. All primary 
deposits (floors, pits, etc.) are sieved in their entirety through 1.0 and $0.5 \mathrm{~cm}$ screen. From every basket within a locus, $10 \mathrm{~L}$ samples of sediment were subjected to flotation and wet sieving with smaller mesh sizes. The result is that even very small basalt fragments can be recovered during the sieving and flotation operations. The heavy fraction operation maximises the chance of basalt debitage recovery. During excavation, the context and archaeological provenance of each basalt artefact was recorded, including the basal elevation. Such care was practiced in order to ensure maximum efficiency in recovery and to properly assign the artefact to an occupational phase and to further identify locations and associations within the neighbourhood.

\subsection{Typology}

A functional typology of the basalt objects from the EBA III levels of Tell es-Safi/Gath was constructed in order to obtain a greater understanding of their use. Artefact typologies are theoretically oriented classifications imposed by the analyst that are designed to investigate specific issues (Gifford 1960; Rouse 1960). In general, the function of an artefact is often discerned from the combination of observed use-wear patterns and shape in a "form equals function” approach (Adams 1999; 2010; Rowan 2014). When possible, the typological categorisation in this study follows the system proposed by Wright (1992) and employs the same terminology. This system has been applied to the analysis of ground stone assemblages from other periods of the southern Levant (e.g., Iron Age Hazor, EBA I Ashqelon-Afridar). It has become a foundation for ground stone analysis in the region due in part to the chronologically static nature of ground stone typologies (Rowan \& Ebeling 2008; Schneider \& LaPorta 2008).

\subsection{Morphometric analysis}

Investigations into craft specialisation have focused on a variety of indicators, namely the scale of production and distributions, the size and locale of debitage, the presence of workshops, and standardisation. The lattermost indicator, standardisation, is perhaps the most utilized. The standardisation hypothesis is as follows: Commodities produced by specialised craftsmen will appear more homogenous in morphology, decoration, or material, than those of non-specialised craftsmen (Blackman et al. 1993; VanPool \& Leonard 2002). The assessment of standardisation is most prevalent in ceramic studies, but has been employed to a lesser extent in chipped and ground stone studies (e.g., Shafer \& Hester 1986; VanPool \& Leonard 2002).

This is because of the difficulty involved in the discernment of craft specialisation through standardisation when addressing reductive technologies (Eerkens \& Bettinger 2001). As such, many lithic standardisation studies have either been unsuccessful or have met with sceptical opposition (e.g., Mallory 1986). Other studies have provided an alternative explanation for observed standardisation that focuses on the functionality of the stone artefacts (Rosenberg 2015; Tzin et al. 2015). We include a brief assessment of standardisation in order to demonstrate the limitations of such inquiry while also gleaning some information on ground stone production. As such, it is expected that ground stone artefacts of the same type exhibit homogeneity in their dimensions. Measurements of these dimensions followed the guidelines of Wright (1992) and values were rounded to the nearest 0.0 or $0.5 \mathrm{~cm}$. 


\subsection{Macroscopic observations}

Two macroscopic characteristics (wear and condition) of the basalt objects were identified and recorded. These assessments were qualitative in nature and involved a visual examination.

\subsubsection{Wear}

An examination of the location and intensity of cultural polish, in the form of use-wear, was performed in order to determine the true function of the basalt artefacts and the extent of use they received. The determination of the intensity of wear was conducted through a visual assessment and was based on a low-high scale. The scale operates as follows: An artefact surface with high wear exhibits considerable sheen, reflects light, and individual grains are difficult to perceive, while an artefact surface with low wear is somewhat smooth to the touch and individual grains are discernible. Cultural polish is discernible from natural polish (e.g., water, wind) in that it occurs differentially on the artefact (Valado 2008). Unlike natural polish, which appears uniform across the whole of an artefact, such as a water-rolled pebble, cultural polish can be expected in specific locations (e.g., face, handle) where an artefact was grasped or repeatedly interacted with another material.

\subsubsection{Condition}

The condition of the basalt artefacts was examined in order to obtain information regarding the nature of recycling and discard. Fracture age was determined as either ancient or modern. Modern or fresh fractures typically occur through excavation or other recent events and are discerned by differences in colour and weathering patterns between the fracture scar and ancient surfaces. The scars of ancient fractures appear more similar in colour and weathering to the rest of the ancient surfaces on the artefact. In addition, the percentage of the original artefact that remained was estimated.

\section{Results}

\subsection{Excavation and recovery}

Colour and texture were the initial variables with which to identify basalt objects. Most basaltic rocks are dark in colour, ranging from dark-green to black depending on the composition of mafic minerals (Allaby 2013: 56). As a quick cooling extrusive rock, basalt is often described as having a fine-grained texture. All basalt objects from Tell es-Safi/Gath were of a similar colour - black.

The basalt objects were distributed throughout the Area E neighbourhood in both Strata E5 and E6 (Figure 3; Table 1). The majority of artefacts are recovered in situ from secondary contexts and are mixed with occupational and architectural debris (walls, alleyway fill, etc.). Very few originate from primary contexts where they were originally utilised. The artefacts are concentrated in the alleyway and courtyard, but others are scattered amongst the adjoining rooms of the four buildings. To date, no basalt debitage has been recovered in the microdebris. 


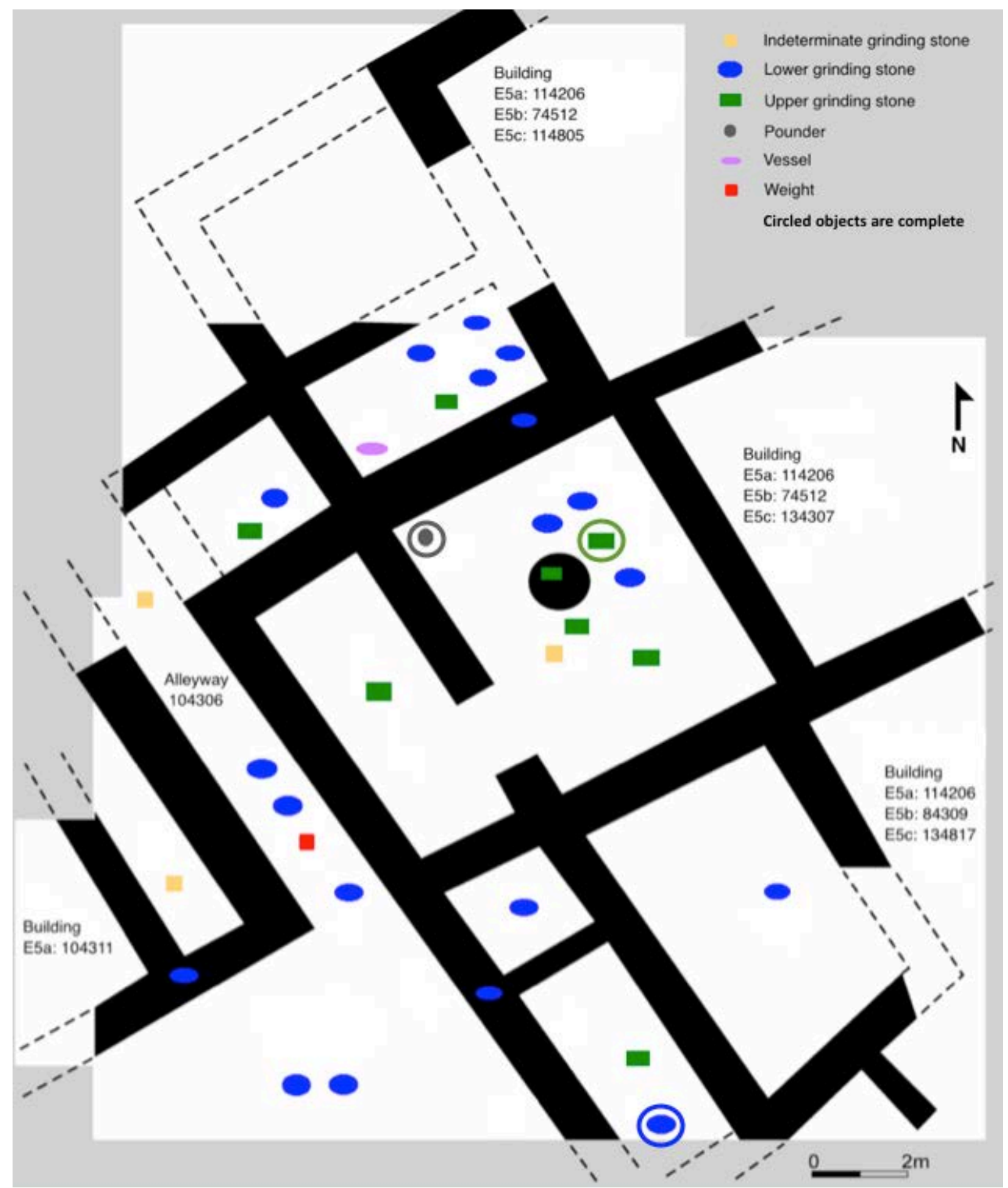

Figure 3. Distribution of basalt artefacts within Tell es-Safi/Gath neighbourhood. 
Table 1. Archaeological context of basalt artefacts. Abbreviations: N/A - not available.

\begin{tabular}{|c|c|c|c|}
\hline Artefact & Stratum & Archaeological Context & Building \\
\hline 1346093 & $\mathrm{E} 5 \mathrm{c}$ & Fill of material under installation 94606 & 134307 \\
\hline E15AQ179 & E6 & Alleyway debris - cultural fill & $\begin{array}{c}\text { Alleyway } \\
104306\end{array}$ \\
\hline 1141073 & $\mathrm{E} 5 \mathrm{a}$ & Pebble floor & 104311 \\
\hline 745019 & $\mathrm{E} 5 \mathrm{~b}$ & Occupational or mudbrick debris on floor 74512 & 74512 \\
\hline 745047 & $\mathrm{E} 5 \mathrm{~b}$ & Occupational or mudbrick debris on floor 74512 & 74512 \\
\hline 745050 & $\mathrm{E} 5 \mathrm{~b}$ & Occupational or mudbrick debris on floor 84805 & 74512 \\
\hline 748114 & $\mathrm{E} 5 \mathrm{a}$ & Occupational or mudbrick debris & 114206 \\
\hline 941057 & E5 & $\begin{array}{l}\text { Encompassed by line of mudbrick debris of } \\
\text { collapsed wall W104107 }\end{array}$ & 104311 \\
\hline 1042042 & E5a & Alleyway debris - cultural fill & $\begin{array}{c}\text { Alleyway } \\
104306\end{array}$ \\
\hline 1143031 & $\mathrm{E} 5 \mathrm{~b}$ & Brown earthy fill beneath floor & 74512 \\
\hline 1144013 & $\mathrm{E} 5 \mathrm{~b}$ & Ash layer of accumulation on floor & 84309 \\
\hline 1347085 & $\mathrm{E} 5 \mathrm{a}$ & Alleyway debris - cultural fill & $\begin{array}{c}\text { Alleyway } \\
104306\end{array}$ \\
\hline 16Е93А050 & E6 & Part of pebble make-up of installation 16E93A06 & N/A \\
\hline 16Е93В070 & $\mathrm{E} 5 \mathrm{a}$ & Alleyway debris - cultural fill & $\begin{array}{c}\text { Alleyway } \\
104306\end{array}$ \\
\hline 16Е93А049 & E6 & Part of pebble make-up of installation 16E93A06 & N/A \\
\hline 1048013 & $\mathrm{E} 5 \mathrm{a}$ & Fill of brown earth and soft grey ash with charcoal & 114805 \\
\hline 748110 & $\mathrm{E} 5 \mathrm{a}$ & Occupational or mudbrick debris & 114206 \\
\hline 16E93B081 & $\mathrm{E} 5 \mathrm{a}$ & $\begin{array}{l}\text { Part of stone wall make-up that is the base for } \\
\text { mudbrick wall W94209 }\end{array}$ & 114206 \\
\hline 16E94A011 & $\mathrm{E} 5 \mathrm{a}$ & In situ on E5a surface, beside pebble installation & 114206 \\
\hline 944090 & $\mathrm{E} 5 \mathrm{a}$ & $\begin{array}{l}\text { Part of stone wall make-up that is the base for } \\
\text { mudbrick wall W74507 }\end{array}$ & 114206 \\
\hline 16E84C012 & E5 & EBA fill surrounding the LB installation $16 \mathrm{E} 84 \mathrm{C} 08$ & 114206 \\
\hline 745029 & $\mathrm{E} 5 \mathrm{~b}$ & Occupational or mudbrick debris on floor 74512 & 74512 \\
\hline 840111 & $\mathrm{E} 5 \mathrm{a}$ & Part of pebble make-up of installation & 114206 \\
\hline 745098 & $\mathrm{E} 5 \mathrm{~b}$ & Occupational or mudbrick debris on floor 74512 & 74512 \\
\hline 748093 & E5a & Occupational or mudbrick debris & 114206 \\
\hline 16E84A007 & $\mathrm{E} 5 \mathrm{~b}$ & Part of make-up of multi-stone installation 94606 & 74512 \\
\hline 1046004 & E5 & EBA winter wash mixed with ash pit & 114206 \\
\hline 1042024 & E5a & Occupational or mudbrick debris & 114206 \\
\hline 746060 & $\mathrm{E} 5 \mathrm{a}$ & Occupational or mudbrick debris & 114206 \\
\hline 1145010 & E5 & In south courtyard surrounding installation 94606 & 114206 \\
\hline 1143010 & E5 & EBA winter wash, encompassed by EBA material & 114206 \\
\hline 16E83C087 & E5a & Alleyway debris - cultural fill & $\begin{array}{c}\text { Alleyway } \\
104306\end{array}$ \\
\hline
\end{tabular}




\subsection{Typology}

Six main types of basalt objects are identifiable in the assemblage (Tables 2 and 3). A common issue encountered in the construction of typologies is the absence of diagnostic features due to the fractured nature of assemblages (Rowan 2003). Any artefact that could not be assigned to a type with full confidence fell under the amorphous category of "fragment". A brief discussion of the typology is included in this paper, but more information on the basalt artefact typology and the entire EBA III Tell es-Safi/Gath ground stone assemblage typology can be found in the forthcoming Tell es-Safi/Gath III volume.

Table 2. Typology and wear of basalt artefacts.

\begin{tabular}{|c|c|c|c|c|}
\hline Artefact & Type & Sub-type & Wear Location & $\begin{array}{c}\text { Wear } \\
\text { Intensity }\end{array}$ \\
\hline 1346093 & Grinding stone & Indeterminate & Face & High \\
\hline E15AQ179 & Grinding stone & Indeterminate & Face & High \\
\hline 1141073 & Grinding stone & Indeterminate & Face & High \\
\hline 16E84C012 & Lower grinding stone & Basin slab or quern & Face & High \\
\hline 1143031 & Lower grinding stone & $\begin{array}{c}\text { Miscellaneous slab or } \\
\text { quern }\end{array}$ & Face & High \\
\hline 941057 & Lower grinding stone & $\begin{array}{c}\text { Modified boulder slab or } \\
\text { quern }\end{array}$ & Face & High \\
\hline 16E94A011 & Lower grinding stone & $\begin{array}{c}\text { Modified boulder slab or } \\
\text { quern }\end{array}$ & Face & High \\
\hline 745019 & Lower grinding stone & Slab or quern fragment & Face & Medium \\
\hline 745047 & Lower grinding stone & Slab or quern fragment & Face & Medium \\
\hline 745050 & Lower grinding stone & Slab or quern fragment & Face & High \\
\hline 748114 & Lower grinding stone & Slab or quern fragment & Face & High \\
\hline 1042042 & Lower grinding stone & Slab or quern fragment & Face & High \\
\hline 1144013 & Lower grinding stone & Slab or quern fragment & Face & High \\
\hline 1347085 & Lower grinding stone & Slab or quern fragment & Face & High \\
\hline 16E93A050 & Lower grinding stone & Slab or quern fragment & Face & High \\
\hline 16Е93В070 & Lower grinding stone & Slab or quern fragment & Face & High \\
\hline 16E93A049 & Lower grinding stone & Slab or quern fragment & Face & High \\
\hline 1048013 & Lower grinding stone & Slab or quern fragment & Face & High \\
\hline 748110 & Lower grinding stone & Slab or quern fragment & Face & High \\
\hline 16Е93В081 & Lower grinding stone & Slab or quern fragment & Face & Medium \\
\hline 944090 & Lower grinding stone & Slab or quern fragment & Face & Medium \\
\hline 745029 & Lower grinding stone & Slab or quern fragment & Face & Medium \\
\hline 840111 & Pounder & Spheroid & Entire & Medium \\
\hline 746060 & Upper grinding stone & Bifacial rectilinear or flat & Faces & High \\
\hline 1046004 & Upper grinding stone & Hand-stone fragment & Face & High \\
\hline 1042024 & Upper grinding stone & Hand-stone fragment & Face & High \\
\hline 745098 & Upper grinding stone & Unifacial loaf hand-stone & $\begin{array}{l}\text { Face, dorsal } \\
\text { side }\end{array}$ & High, low \\
\hline 748093 & Upper grinding stone & Unifacial loaf hand-stone & $\begin{array}{l}\text { Face, dorsal } \\
\text { side }\end{array}$ & High, low \\
\hline 16E84A007 & Upper grinding stone & Unifacial loaf hand-stone & $\begin{array}{l}\text { Face, dorsal } \\
\text { side }\end{array}$ & High, low \\
\hline 1145010 & Upper grinding stone & Unifacial loaf hand-stone & $\begin{array}{l}\text { Face, dorsal } \\
\text { side }\end{array}$ & High, low \\
\hline 1143010 & Vessel & Rim fragment & $\mathrm{N} / \mathrm{A}$ & N/A \\
\hline $16 \mathrm{E} 83 \mathrm{C} 087$ & Weight & Suspension weight & Perforation & Low \\
\hline
\end{tabular}


Table 3. Metric data of basalt ground stone artefacts. Units are centimeters and bold font indicates intact dimensions.

\begin{tabular}{|c|c|c|c|c|}
\hline Artefact & Length & Width & Thickness & Weight (g) \\
\hline 1346093 & 5.5 & 4 & 4 & 104 \\
\hline E15AQ179 & 5 & 4 & 2 & 57.5 \\
\hline 1141073 & 5 & 4 & 3 & 157 \\
\hline 745019 & 11 & 8 & 3.5 & 311 \\
\hline 745047 & 12.5 & 6.5 & 5 & 657.5 \\
\hline 745050 & 15.5 & 11 & 4 & 735 \\
\hline 748114 & 10 & 7.5 & 4 & 380 \\
\hline 941057 & 23 & 21 & 7 & 2578 \\
\hline 1042042 & 9 & 5 & 3 & 327.5 \\
\hline 1143031 & 19 & 16 & 4 & 1292.5 \\
\hline 1144013 & 11 & 7 & 3.5 & 469.5 \\
\hline 1347085 & 4.5 & 4 & 4 & 182.5 \\
\hline 16E93A050 & 6 & 6 & 4 & 139 \\
\hline 16Е93В070 & 6.5 & 6 & 3.5 & 123 \\
\hline 16E93А049 & 7 & 7 & 4 & 315.5 \\
\hline 1048013 & 13 & 10 & 3 & 418.5 \\
\hline 748110 & 14.5 & 12 & 3 & 762 \\
\hline 16Е93В081 & 9 & 9 & 2.5 & 270.5 \\
\hline 16E94A011 & 42 & 22 & 10 & 17579.5 \\
\hline 944090 & 11 & 10 & 3 & 640.5 \\
\hline 16E84C012 & 29 & 26 & 12 & 8457.5 \\
\hline 745029 & 9 & 8 & 4 & 218 \\
\hline 840111 & & & & 221 \\
\hline 745098 & 11 & 9 & 5.5 & 721 \\
\hline 748093 & 10 & 8.5 & 4 & 497 \\
\hline 16E84A007 & 14 & 10.5 & 5 & 1160.5 \\
\hline 1046004 & 9.5 & 5 & 4 & 174.5 \\
\hline 1042024 & 4.5 & 3 & 4 & 62 \\
\hline 746060 & 12 & 7 & 5.5 & 1004 \\
\hline 1145010 & 7 & 7.5 & 4.5 & 322 \\
\hline 1143010 & 6.5 & 6.5 & $\begin{array}{l}2.5 \text { thickest, } \\
1 \text { at rim }\end{array}$ & 121 \\
\hline 16E83C087 & & & 1 & 14.5 \\
\hline
\end{tabular}

Pounder ( $\mathrm{n}=1)$. The sole pounder (Basket \#840111) is made of compact basalt and is easily operable with one hand. It is nearly spherical in form and exhibits wear from pecking and battering. However, a few dulled edges are identifiable and demarcate several polished, faceted surfaces where abrasive wear occurred, pointing to the multi-purpose nature of the tools (Rowan et al. 2006).

Vessel ( $n=1)$. A rim fragment of a vessel (Basket \#1143010) made of compact basalt was identified among the assemblage of basalt objects. This artefact exhibits a well-defined rim with a slight flare and a gradual tapering of the walls upwards to the rim. It contains parts of the walls, but nothing of the base. Significant exterior and interior finishing suggests skilled craftsmanship and distinguishes it from small mortars (Wright 1992). The diameter of the 
vessel is estimated at $15-18 \mathrm{~cm}$, but because of the fractured nature of the artefact, it cannot be typed further than as a rim fragment.

Weight $(n=1)$. The only perforated artefact (Basket \#16E83C087) is made of compact basalt and likely served as a weight. Based on its dimensions and weight, it can be typed as a spindle whorl (Wright 1992; Rowan et al. 2006), but it has a higher perforation diameter to artefact diameter ratio than other spindle whorls. In addition, it is ringed rather than discoidal and slightly askew, making it unbalanced. As such, it may have functioned as a suspension weight where balance was less important.

Upper grinding stones ( $n=7)$. This is the second most abundant type of basalt objects in the assemblage. A convex use-face and a size and weight that allow the artefact to be mobile are the most defining features of upper grinding stones (Wright 1992; Rowan 2014). These are found on each basalt upper grinding stone in the assemblage. Four unifacial loaf handstones (Baskets \#745098, \#748093, \#1145010, and \#16E84A007) were identified from the distinct single use-face and the curvature of the exterior sides that gives these artefacts the signature "loaf" form (Figure 4). A complete, bifacial rectilinear or flat hand-stone (Basket \#746060) was also identified. It exhibits a rectangular form in overhead or plan view and dual opposing parallel use-faces and straight sides. At $12 \mathrm{~cm}$ in length and $1004 \mathrm{~g}$ in weight, this artefact could be comfortably operated by one hand. Lastly, two hand-stone fragments were recovered, but they could not be further identified to a more specific type.

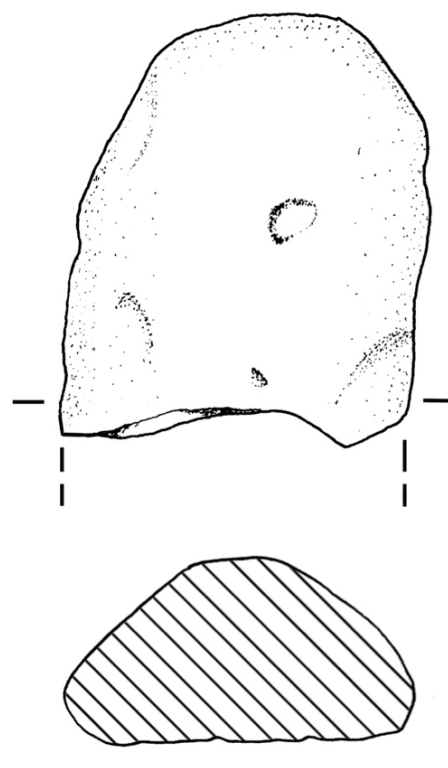

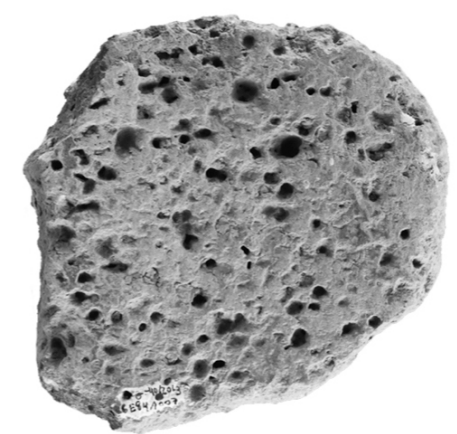

16E84A007
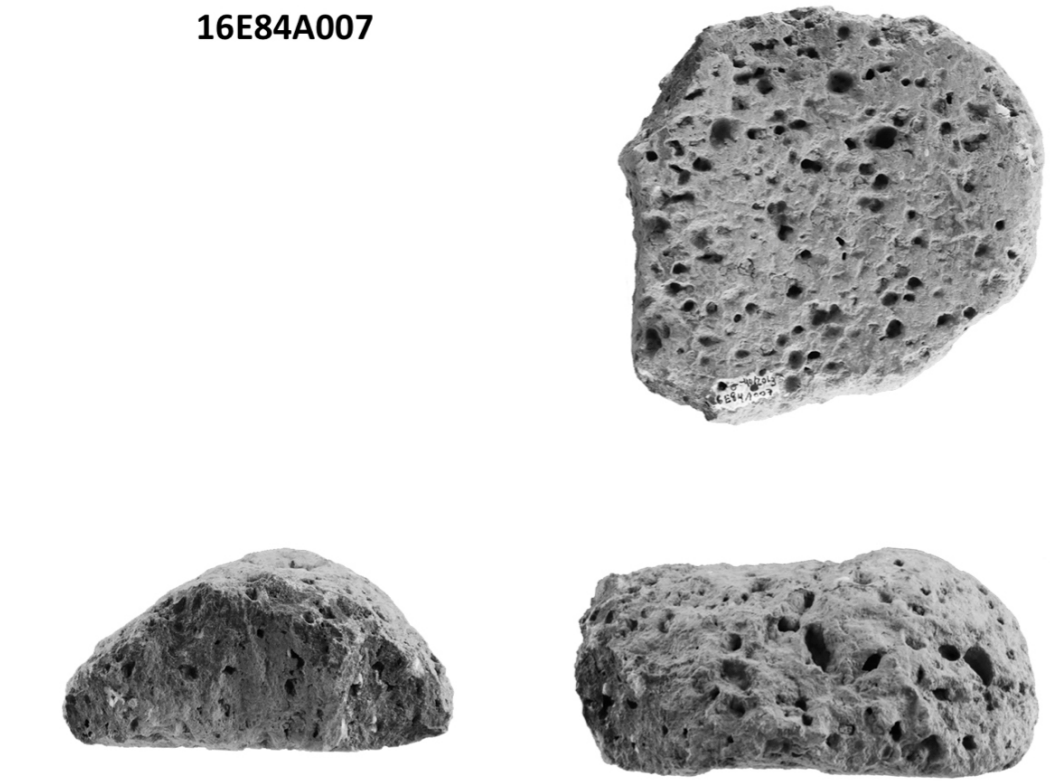

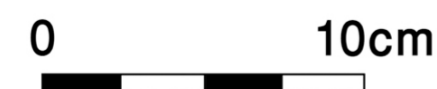

Figure 4. Illustration and picture of unifacial loaf hand-stone.

Lower grinding stones $(\mathrm{n}=19)$. This is the most abundant artefact type. Lower grinding stones are identified based on several criteria: Concave use-face in cross section, large size, and an inability to operate the artefact by hand (Wright 1992; Rowan 2014). Slabs display rectangular use-surfaces with lateral striae, while querns display oval use-surfaces with rotary striae (Wright 1992). One type of lower grinding stone is a basin slab or quern (Basket \#16E84C012). This large artefact exhibits thick and well-defined ridges that demarcate the extent of the use-surface, but as most of the use-surface is absent, it cannot be determined whether the artefact is a slab or quern. Another type of lower grinding stone is modified boulder slabs and querns (Baskets \#16E94A011 and \#941057). These lack a stable base and 
are large, bulky, and crude in form. They do not display significant rotary or lateral striae and their oval use-surfaces are due to the shape of the stone rather than the movement of an upper grinding stone. The rounded sides extend downward and meet under the artefact, thereby creating a u-shaped pattern in cross section. This makes the centre of the artefact thicker than the perimeter. Baskets \#1143031 and \#745050 are typed as miscellaneous slabs and querns as they do not suitably fall into one of Wright's (1992) types. These are similar to the modified boulder slabs and querns with exception of the thickness. They retain a slightly concave usesurface and are overall thin, particularly at the edges of the use-surface, resembling a pancake in form. The fractured nature of the remaining fourteen lower grinding stones does not permit them to be further typed and they fall under the general type of slab or quern fragment.

Indeterminate grinding stones $(n=3)$. Several very small basalt objects were recovered that exhibited a level use-surface, worn from repeated grinding and abrasion, and lacked a dorsal side or second use-surface. Given their fractured nature, it could not be determined whether they originated from an upper or lower grinding stone.

\subsection{Morphometric analysis}

The fractured nature of the basalt objects, particularly the length dimension, substantially compromises the analysis (Table 3). However, some information is obtained from the intact thickness and width measurements of the upper grinding stones.

Of the upper grinding stones, only the four unifacial loaf hand-stones can be assessed as they are of the same type (Figure 4; Table 4). Their intact width and thickness dimensions are of similar values respectively with a very small range, particularly among the thickness values. As only the end portion remains of Basket \#1145010, it is probably that it would have increased in width by 1-2 cm down the body. Any grinding stones that are freshly produced from a workshop would have an additional $1-2 \mathrm{~cm}$ of material on their use-face, as this amount is lost over the course of the artefact's life (e.g., Adams 2014b). If this additional material is accounted, the average thickness increases, but does not significantly influence the interpretation. These artefacts are large enough to be operated with two hands.

Table 4. Metric data for unifacial loaf hand-stones. Units are in centimetres and bold font indicates intact dimensions.

\begin{tabular}{lcccc}
\hline Artefact & Length & Width & Thickness & Sub-type \\
\hline 1145010 & 7 & 7.5 & 4.5 & Unifacial loaf hand-stone \\
745098 & 11 & 9 & 5.5 & Unifacial loaf hand-stone \\
748093 & 10 & 8.5 & 4 & Unifacial loaf hand-stone \\
16E84A007 & 14 & 10.5 & 5 & Unifacial loaf hand-stone \\
Range & & 3 & 1.5 & \\
Mean & & 8.875 & 4.75 & \\
\hline
\end{tabular}

Although a small sample, the similar width and thickness dimensions for upper grinding stones of the same morphology (unifacial and loaf-shaped) are tentatively indicative of stylistic standardisation (for a similar assessment see Tzin et al. 2015). It should be noted that this standardisation does not signal craft specialisation. Rather, these hand-stones were manufactured to a common rubric in order to produce tools of a consumer-preferred form, not necessarily an aesthetic preference, which still ensured sufficient functionality. As such, they were an appropriate size and weight for consumers to operate without the fingertips being caught between the two interacting surfaces (Adams 2014a: 103). 


\subsection{Macroscopic observations}

\subsubsection{Wear}

In general, the recovered basalt artefacts display a high degree of wear (Table 2). The face of every grinding stone experienced a sufficiently large amount of use to develop the degree of sheen and levelling of the surfaces that they now exhibit. Similarly, the dorsal sides of upper grinding stones exhibit smoothing and mild cultural polish from repeated interaction with a soft surface, likely the palms of the operators. Both the exterior and interior of the weight are moderately worn. The location and intensity of wear, particularly that of the grinding stone faces, indicate that the artefacts were used for their morphologically suggested function (Adams 2010).

\subsubsection{Condition}

The basalt ground stone assemblage is heavily fractured. The physical condition of each artefact was assessed through a visual inspection of fracture scars and an estimation of the remaining percentage of the original artefact (Figure 5). Only three artefacts were discovered intact. The majority of the artefacts $(n=24)$ exhibit ancient fractures with most having threefive different scars. In addition, most of the artefacts $(n=27)$ represent less than $50 \%$ of the original stone tool. With the exception of one artefact (Basket \#1141073), the different fractured artefacts could not be matched together to form a larger parent artefact.

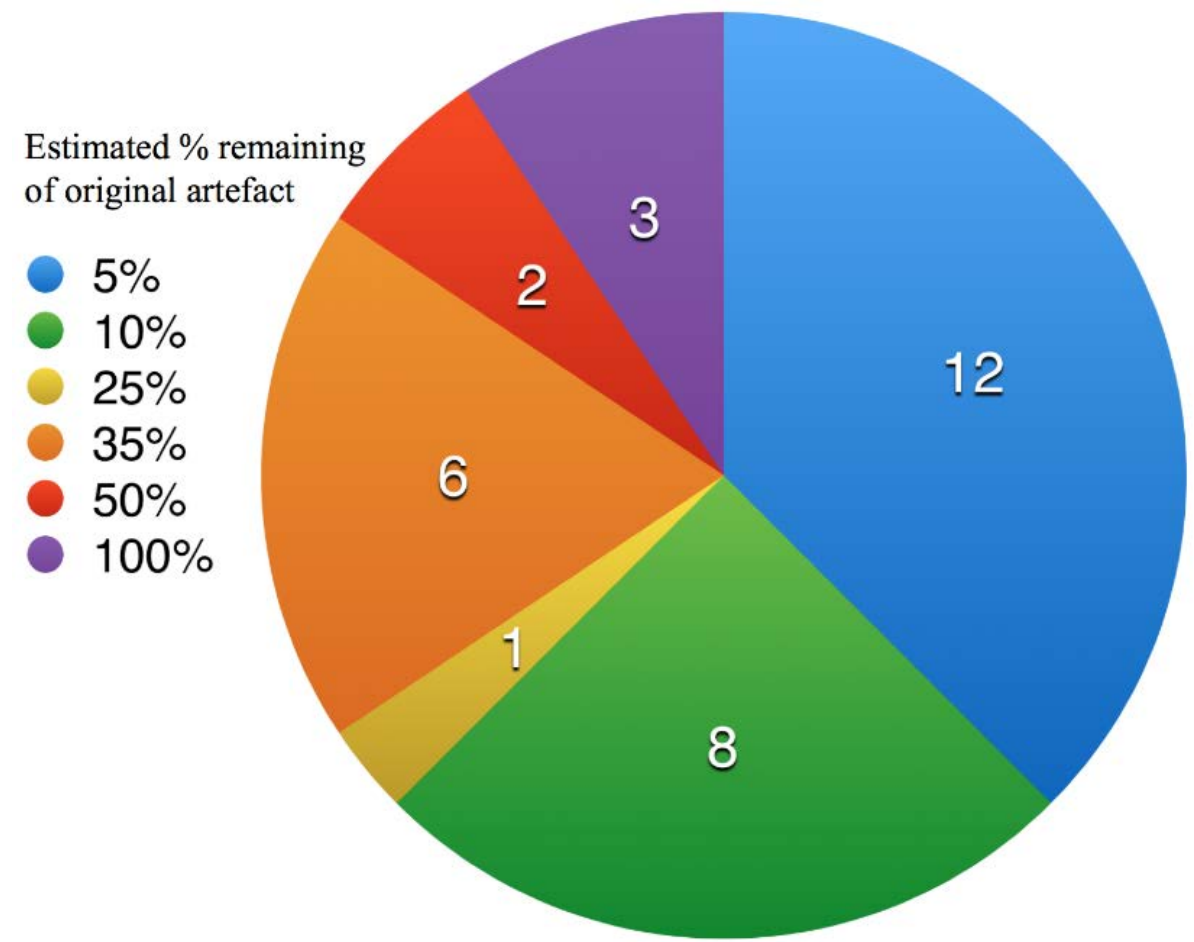

Figure 5. Condition of the basalt artefacts.

Most artefacts were not used to the point of material exhaustion and it is fruitless to speculate how they became so fractured since there are so many possibilities, ranging from growing structural instability over time or accentuated pre-existing fractures to simply being dropped (or even thrown) at inopportune times. With extended use, lower grinding stones gradually become less useful as they thin and may perforate when the central depression becomes too deep (Adams 2008). Alternatively, they may be recycled as other ground stone artefacts. 


\section{Discussion: Life-history of basalt artefacts}

There are four main stages in the life history of basalt ground stone artefacts. The evidence for each stage at Tell es-Safi/Gath is discussed in the sections that follow.

\subsection{Stage 1: Production}

The first stage of the life-history of an artefact is production. There are two sub-stages to production: Procurement of the raw material and manufacture, the reduction of material.

\subsubsection{Procurement of raw material}

Basalt sources are located in several regions of the Near East, namely Egypt, Dead Sea, Golan-Galilee, and a smaller source in Mitzpe Ramon. While there are two small outcrops of basalt in the Judean Foothills (shephelah) in the region of Tell es-Safi/Gath, these sources are described as poorly exposed and heavily weathered (Gvirtzman \& Buchbinder 1969). Consequently, these would not have served as suitable sources from which to produce ground stone tools (Rutter 2003). Based on suitability and proximity to Tell es-Safi/Gath, there are two regions that are considered to be the most likely candidates for the source(s) of procurement (Milevski 2008; 2011: 108-113).

Of these regions, the nearest is situated ca. $60 \mathrm{~km}$ to the east along the Jordanian side of the Dead Sea where basalt sources appear in small occurrences, such as the Ma'in and Kerak areas (Steinitz \& Bartov 1992; Shawabekeh 1998). The other region is the Golan-Galilee, located ca. $90 \mathrm{~km}$ northeast of the settlement (Sneh et al. 1997; Weinstein 2000). Both regions contain geologically young (Miocene-Pleistocene) sources that have experienced less weathering than older sources (Steinetz \& Bartov 1992; Sneh et al. 1997), making them of better quality for producing vessels and tools (Gluhak et al. 2015). Previous provenance studies have linked the distribution of Chalcolithic and EBA I basalt vessels within the Levant to the Dead Sea sources (Philip \& Williams-Thorpe 1993).

Settlements within the Golan-Galilee region have reported a high frequency of basalt artefacts in their ground stone assemblages (e.g., Dan, Hazor, Bet Yerah, Te'o). The occupants of these settlements likely procured their raw material from these sources, which, given their close if not immediate proximity, could be accomplished within a single day round-trip from the workshop, despite the difficult logistics to transport blanks over any great distance (Rutter \& Philip 2008). Procurement of this nature can be regarded as local (Fratt \& Biancaniello 1993), as craftsmen took advantage of their geographic location and exploited resources that were available within the immediate landscape (Schneider \& LaPorta 2008). This distance is similar to the ethnographic observations of Mayan lower grinding stones craftsmen in the Guatemalan highlands who travelled 3-12 km to quarries and riverbeds for blanks (Hayden 1987).

Standard models of ground stone production involve the procurement of blanks and their initial reduction to rough-outs at the quarry before being transported back to a workshop for further (secondary) reduction and finishing (Wright 1992; Abadi-Reis \& Rosen 2008; Ebeling \& Rosenberg 2015). Unfortunately, no EBA site from the southern Levant has produced evidence of such negatives, discarded blanks, or other evidence of quarrying activities to be identified as a basalt quarry or production site (Abadi-Reis \& Rosen 2008; Milevski 2008).

\subsubsection{Manufacture and material reduction}

Beasts of burden, such as donkeys, which are domesticated immediately prior to this period and spread throughout the region quickly (Greenfield et al. 2012; Grigson 2012), may 
have served as the mode of transportation for rough-outs and blanks from the sources to workshops (Andrefsky Jr. 1994; Schneider \& LaPorta 2008). However, information on the manufacture of basalt ground stone artefacts is lacking due to the absence of workshops, even among the many EBA sites in proximity to the potential northern quarry sites (Milevski 2008).

Even in the urban settlements that are acquiring ground stone commodities, such as Tell es-Safi/Gath, the absence of basalt debitage suggests that manufacture, in the form of secondary reduction, occurred external to the neighbourhood. Given the lack of reports of similar absence of basalt debitage at most EBA sites in the north, it is plausible that manufacture occurred proximate to the source (Abadi-Reis \& Rosen 2008).

The absence of definitive workshops raises the question as to whether productive specialisation existed in the EBA of the southern Levant with respect to ground stone production. The question of specialised production is difficult to investigate because of the small number of remains, the fractured nature of the assemblage, and the underdevelopment of this area of inquiry for ground stone technology. Based upon ethnographic analogy, one can infer from the absence of such evidence that there is little likelihood of productive specialisation in ground stone tool production (Schneider 1996). This scenario stands in contrast to the situation in the Middle Bronze through Iron Ages where such specialisation in the form of workshops is evident (Sparks 2001; Ebeling \& Rosenberg 2015). While there is some evidence for skilled craft production in the form of the vessel rim fragment (Basket \#1143010), it is probable that there were proficient craftsmen during the EBA, particularly for the manufacture of stone vessels (Braun 1990; van den Brink et al. 1999). Furthermore, there is also an active tradition for the production of ground stone mace heads during the EBA I (Rosenberg 2010) and one made of basalt was recently discovered in Area P of Tell esSafi/Gath.

Therefore, even though there is evidence for skilled craftsmanship on some of the basalt ground stone artefacts, evidence for specialised craft production could not be identified. The observed morphological similarity of the unifacial loaf hand-stones can be suggested to be a by-product of the ground stone functionality, rather than the organisation of production (Costin 2005). In this sense, any standardisation is likely due to the manufacture of artefacts according to the same operational rubric, specifically the need to operate an upper grinding stone by hand and possibly for stylistic purposes.

Many of the basalt objects retain crude features and some (Baskets \#16E94A011, \#745019, and \#941057) exhibit an asymmetrical morphology that suggests little effort was expended in manufacture, save for an attempt to level the working face. To reinforce the informal nature of production, some of the ground stone tools were crudely fashioned from loose boulders, such as Baskets \#941057 and \#16E94A011, since they lack formal shaping and finishing altogether. This suggests that embedded procurement and opportunistic behaviour may have been a regular occurrence and ground stone production may have occurred at the same time as other activities were being carried out (Abadi-Reiss \& Rosen 2008) - in other words, it was not performed by specialists for the most part. Overall, the assemblage is manufactured for utilitarian purposes with the intention of being functional tools.

\subsection{Stage 2: Distribution}

The middle stage of an artefact's life-history and the one that is most difficult to assess is their spatial distribution from source. This stage addresses their transportation from the locale of production to the locale of consumption, Tell es-Safi/Gath, and their redistribution within 
the settlement to the residents. As a result, this involves an examination of both non-local and local exchange systems.

\subsubsection{Non-local exchange}

The nature of distribution is difficult to establish and its interpretation is often rooted in theoretical models. Yet, we can document where, not necessarily how or why, commodities were moved.

The basalt objects were transported over a distance of approximately 60-90 km from the northern and eastern reaches of the southern Levant to Tell es-Safi/Gath. Given the distance between Tell es-Safi/Gath and these sources, it is likely that some kind of organised distribution system existed to provide distant settlements with sufficient quantities of ground stone at an inexpensive enough rate for them to be used in non-elite domestic activities and discarded in related contexts. Although it is possible that the residents of Tell es-Safi/Gath organised their own expedition to bring the goods to them, this movement is best explained through the operation of merchants along well-known regional and inter-regional exchange routes within the Levant (Milevski 2011: 108-113; Savage 2011). During the EBA I, basalt vessels and spindle whorls were transported from the southern Levant to Egypt (Porat \& Seeher 1988; Savage 2011). However, it cannot be determined if merchants travelled directly to Tell es-Safi/Gath or stopped at each urban centre along their route, such as a down-the-line model.

The non-local exchange of basalt objects during the EBA was facilitated by beasts of burden, specifically after the domestication of the donkey (Greenfield et al. 2012; Grigson 2012). Old and Middle Kingdom Egyptian hieroglyphic texts attest to the large-scale exploitation of donkeys in merchant caravans between Egypt and neighbouring regions (Midant-Reynes 2000). As a result, basalt objects received a wide distribution within the southern Levant and are discovered at most EBA sites within the shephelah (Milevski 2008). The evidence of donkey-related finds and commerce at EBA III Tell es-Safi/Gath (Greenfield et al. 2012) strengthens the assumption that the basalt objects did in fact arrive through this mode of transportation. Although this paper discusses unidirectional exchange, it is likely that, in the assumed absence of an exchange medium, such as cash (coinage of gold, silver, or other metals), basalt objects were exchanged for other commodities or even labour (Masson 2005; Silver 2007). Situated in the arable shephelah, Tell es-Safi/Gath likely produced and exported perishable commodities (e.g., textiles, olive oil, grain, fruit).

Nearby Tel Yarmuth has long been regarded as the dominant urban centre in the shephelah (de Miroschedji 1999; 2003; 2006). Under this assertion, Tell es-Safi/Gath was considered as a secondary settlement beneath Tel Yarmuth. The recent excavations at Tell esSafi/Gath have challenged this position and prompted an alternative view of the site as an equally prominent and therefore competing urban centre (Shai et al. 2014). In this regard, Tell es-Safi/Gath would be a primary recipient of basalt ground stone artefacts that were being brought from the north, rather than receiving commodities via a secondary exchange network emanating out of Tel Yarmuth.

\subsubsection{Local exchange and redistribution}

It is not clear whether basalt objects were distributed to the commoner residences in Area E through a decentralised (e.g., market) or centralised redistribution system. There are some hints, however. The domestic assemblage recovered from each household in the Tell esSafi/Gath neighbourhood contained similar frequencies and types of basalt artefacts, which suggests that that each household had a similar form of and potentially equal access to these 
commodities. Two of the three complete basalt objects, an upper grinding stone (Basket \#746060) and a pounder (Basket \#84011), were discovered in the courtyard of Building 1142046, while the third complete artefact, a lower grinding stone (Basket \#16E94A011) was discovered in the same building, but in an adjacent room. The distribution pattern of the thirty-two basalt objects suggests that there was a lack of social or economic differentiation within the neighbourhood. No household was socially or economically limited or prohibited from acquiring such basic subsistence-related artefacts.

In light of these observations, it can be argued that a centralised authority organised the redistribution of imported basalt objects to their subjects (Bates \& Lees 1977; Wright 2014). This scenario is similar to the ground stone distribution system practiced among pre-contact Mesoamerican (Maya and Olmec) societies where merchants would transport ground stone commodities collected from the highlands to the ruling elite of lowland communities, who would then redistribute these commodities to lowland households (Rathje 1972). The discovery of imposing public buildings (possible palace?) at nearby Tell Yarmuth suggests the presence of elite in such EBA urban centres. However, no EBA elite structures have been excavated as yet at Tell es-Safi/Gath, namely because we are excavating at some distance from the acropolis or summit of the tell where such structures are most likely to exist. Furthermore, there is no evidence of storehouses or the stockpiling of basalt ground stone artefacts in any EBA elite structure, including at Yarmuth, which might shed light on the nature of control and distribution of such resources.

Similarly, one can argue from a more social perspective that the relatively uniform distribution of basalt objects among houses and rooms might simply reflect similarities in the status and roles of the occupants of such structures given the similarities in their size and layout. As such, the nature of the distribution system within Tell es-Safi/Gath is speculative at present.

\subsection{Stages 3 and 4: Consumption and discard}

The final stages in the life-history are consumption and discard. They are discussed together as they are often intertwined in the archaeological record (Wright 2014).

\subsubsection{Consumption}

The recipients of these basalt ground stone commodities were domestic households in the Tell es-Safi/Gath neighbourhood. The collective function of the basalt objects, based on their typology, is reflective of domestic activities, namely food preparation (Rowan et al. 2006; Adams 2014a: 137-141). In general, grinding stones were important tools for the agroeconomic societies of the EBA southern Levant, as they processed cereal products through abrasive and compacting forces (Ebeling \& Rowan 2004). The high amount of wear and sheen on their surfaces suggests that they were extensively used and points to the overall utilitarian nature of the basalt artefacts.

The courtyard of Building 74512/114206 likely played a central locale in food preparation. Not only does it contain the highest count of basalt grinding stones, but, perhaps more importantly, a complete upper grinding stone and a complete pounder were recovered from this room. Additional evidence for the role of this locus is provided by the presence of cooking vessels, stone installations, and other grinding stones of non-basalt material (Shai et al. 2014). This organisation of domestic space use was not uncommon in EBA settlements of the southern Levant (Ebeling \& Rowan 2004). An analogous example of the use of a courtyard for food preparation is found at Bet Yerah (Paz 2012). The adjacent room to the courtyard in Building 114206 contains a large complete lower grinding stone (Basket 
\#16E94A011) in situ next to a pebble cooking installation. Consequently, food preparation occurred in several locations within the same E5a building.

However, the finely crafted basalt vessel does not fit with the apparent utilitarian nature of the ground stone assemblage. Such vessels are considered prestige items, particularly during the EBA I (Braun 1990; van den Brink et al. 1999). Its discovery, coupled with that of other EBA exotic artefacts (e.g., ivory cylinder seal, mace heads), hint that the occupants of the EBA III neighbourhood at Tell es-Safi/Gath may have had a higher socio-economic status than originally assumed (Maeir et al. 2011).

\subsubsection{Discard}

The fractured nature of basalt artefacts is directly relevant for understanding the consumption and discard of these artefacts. The alleyway appears as the primary location for active discard, whether to level the alley floor or simply to dispose of trash (Shai et al. 2014). The basalt artefacts discovered in the alleyway are all highly fractured (many only represented by an estimated $5 \%$ of the original artefact) and were likely discarded after fracturing since none could be refitted. Because of the ancient nature of the multiple fractures, their exact cause cannot be determined. Some may been purposely broken in order to facilitate discard or to serve secondary use-lives (Baysal \& Wright 2005), or incidentally fractured when dropped by residents or by depositional forces, such as the collapse of the roof and walls.

While some basalt objects were actively discarded in the alleyway, others were recycled. This alternative to discard resulted in several artefacts experiencing a sequential secondary use-life (Adams 2014a: 24-28). The use of these artefacts for building or repairing walls and floors was unlikely for their basaltic nature or to conserve material, but rather because of convenience and availability - just a useful stone to fill a gap (Wright 2008). This interpretation is supported by the inclusion of non-basalt ground stone artefacts in walls, which further demonstrates a lack of preference for a specific building material type. Still other specimens (e.g., Baskets \#16E93A049 and \#16E93A050) might have had a more aesthetic role. These two were placed on their side so that their use-surfaces, covered with smooth sheen, were exposed and lined the concave interior of a pebble installation.

These two basalt objects were not used to the point of exhaustion and were likely discarded or recycled because of their fractured nature. The function of the installation (Basket \#16E93A06) is not completely clear, but one likely function was as a cooking surface. Ultimately, the use of artefacts beyond their primary function stems from convenience, rather than from necessity and a scarcity of resources. It also suggests that longterm habitation (Adams 2014a: 24-25), as a residential pattern, appears to be the norm in this neighbourhood based on the evidence for architectural continuity between EBA III horizons (Shai et al. 2012; 2014).

It is thought that there is a direct relationship between the value of a commodity and its distance from the source and an inverse relationship between the value and volume of artefacts distributed (Earle \& Ericson 1977; Renfrew 1977). In the case of Tell es-Safi/Gath and the shephelah, basalt artefacts are found far from the nearest sources (ca. $60 \mathrm{~km})$. They would not be "cheap" or easy to acquire in this model. Given the raw material properties of basalt, these artefacts were an important household commodity and likely had a high use value. Basalt is durable, sheens and smooths well, and leaves considerably less grit in the processed meal in comparison to other materials (Ebeling \& Rowan 2004; Schneider \& LaPorta 2008).

At the same time, there are hints that they are not expensive "exotic" materials that have prestige value. In terms of NISP, basalt objects constitute a large percentage ( $\mathrm{ca}$. 35\%) of the entire ground stone assemblage, but are more fractured. Along the same lines, the acquisition 
of basalt commodities does not appear to be entirely out of necessity due to the availability of local raw materials. The relative excess of these commodities would have increased the ease of their acquisition and would have decreased their exchange value. Because basalt objects were widely distributed and commonly imported commodities during the EBA around the southern Levant, it is likely that their exchange value, the cost of acquisition, was low. Therefore, basalt ground stone artefacts were both affordable to and valued by non-elite residents.

\section{Conclusion}

\subsection{Summary}

This paper is an attempt to reconstruct various aspects of the life-history of basalt ground stone artefacts from an EBA III domestic neighbourhood at Tell es-Safi/Gath. In doing so, it has illuminated several key characteristics of their journey. However, the small assemblage and fractured nature allow for only a linear model of the life-history to be constructed.

It is not clear whether the basalt objects were produced by specialised craftsmen, while others (e.g., vessels) may have been. However, it is likely that some craftsmen were proficient at their craft, but full time employment was not necessary given the long use-life of grinding stones. The presence of a well-finished basalt vessel, a notable tradition during the Chalcolithic and EBA I, may signal the continuation of a specialised production system for such objects.

The lack of basalt debitage at Tell es-Safi/Gath suggests that any secondary reduction likely took place outside the neighbourhood. In all likelihood, the basalt objects were procured from basalt sources within the southern Levant, namely those in the Golan-Galilee region or along the eastern side of the Dead Sea, and manufactured to completion near these locations. The basalt commodities were probably distributed from there to the south and west by networks of merchants, independently or sponsored by city authorities, who organised caravans of donkeys to carry the heavy loads. There are Near Eastern examples of both from the Early and Middle Bronze Ages (Veenhof 1997; Atici 2014).

There is no evidence for differential access to basalt commodities within the Tell esSafi/Gath neighbourhood. Given the similarity in distribution between each of the houses and the relatively high frequency of basalt objects in the ground stone assemblage, it is suggested that local exchange through redistribution of the imported basalt commodities was organised by a central authority.

The domestic activities of the residents and the extensive use of the basalt ground stone artefacts are reflected in the functional typology of the assemblage and the wear on their faces. Basalt was not valued for its material properties once the artefact was fractured, as none exhibit indications of a secondary use-life as another tool. Instead, most were actively discarded in the alleyway, while others were recycled as part of the make-up of walls, floors, and installations.

\subsection{Significance of findings}

The movement of basalt ground stone commodities are evidence of the nature of connection between the inhabitants of Tell es-Safi/Gath to the production centres in the north and eastern of the southern Levant. However, it is likely that Tell es-Safi/Gath was not dependent upon other polities for basic subsistence resources, which would not transport well over great distances. 
Our excavations of a non-elite neighbourhood with its substantial evidence for the presence of non-local ground stone artefacts in each building suggest that such goods were not expensive even though they were not locally produced. Each household is provided or has access to such objects that were fundamental to the processing of basic foods. If the quantity of such goods is multiplied across the entire site, it further suggests that the exchange network between Tell es-Safi/Gath and the production regions was substantial and long lasting. Given the large size (ca. 24 ha) of Tell es-Safi/Gath and volume of imported artefacts, it is clear that Tell es-Safi/Gath was a prominent urban centre at the pinnacle of the local EBA political and economic system (Shai et al. 2014).

The fractured nature of ground stone assemblages and a lack of extensive provenance data have stymied the construction of a comprehensive model for the basalt ground stone industry of the EBA III southern Levant (Milevski 2008). Despite these obstacles, this study can represent a significant step forward in the reconstruction of socio-economic relations between the urban centres of the shephelah and the production centres to the north and east during the EBA III. It also supports previous hypotheses regarding the nature of the basalt industry (see Milveski 2008; 2011). Furthermore, this study highlights the important role that even the most mundane artefacts in EBA daily life can have upon our understanding of early urban lifestyles.

\section{Acknowledgments}

The authors would like to thank the many staff, students, and volunteers of the Ackerman Family Bar-Ilan University Expedition to Gath. D. Levin deserves credit for the illustrations of the artefacts. Funding was provided through the Social Sciences and Humanities Research Council of Canada, Bar-Ilan University, the University of Manitoba, and the Near East and Biblical Laboratory of St. Paul’s College.

\section{References}

Abadi-Reis, Y., \& Rosen, S.A. 2008, A chip off the old millstone: Grinding stone production and distribution in the Early Bronze Age of the Negev. In: New Approaches to Old Stones: Recent Studies of Ground Stone Artifacts (Rowan, Y.M., \& Ebeling, J.R., Eds.), Equinox Publishing Ltd., London: p. 99-115.

Ackermann, O., \& Bruins, H.J. 2012, The environmental background of Tell es-Safi/Gath and its vicinity. In: Tell es-Safi/Gath I: The 1996-2005 Seasons (Meir, A.M., Ed.), Harrassowitz, Wiesbaden: p. 123-132.

Adams, J.L. 1999, Refocusing the role of food-grinding tools as correlates for subsistence strategies in the U.S. southwest. American Antiquity, 64: 475-498. doi:10.2307/2694147

Adams, J.L. 2008, Beyond the broken. In: New Approaches to Old Stones: Recent Studies of Ground Stone Artifacts (Rowan, Y.M., \& Ebeling, J.R., Eds.), Equinox Publishing Ltd., London: p. 213-229.

Adams, J.L. 2010, Understanding grinding technology through experimentation. In: Designing Experimental Research in Archaeology, Examining Technology through Production and Use (Ferguson, J.R., Ed.), University Press of Colorado, Boulder: p. 129-151.

Adams, J.L. 2014a, Ground Stone Analysis: A Technological Approach. University of Utah Press, Salt Lake City, 336 p. 
Adams, J.L. 2014b, Ground stone use-wear analysis: A review of terminology and experimental methods. Journal of Archaeological Science, 48: 129-138. doi:10.1016/j.jas.2013.01.030

Allaby, M. 2013, A Dictionary of Geology and Earth Sciences. Oxford University Press, Oxford, $672 \mathrm{p}$.

Andrefsky Jr., W. 1994, Raw-material availability and the organization of technology. American Antiquity, 59: 21-34. doi:10.2307/3085499

Atici, L. 2014, The secondary products revolution in light of textual evidence from KultepeKanesh, central Turkey. In: Animal Secondary Products: Domestic Animal Exploitation in Prehistoric Europe, the Near East and the Far East (Greenfield, H.J., Ed.), Oxbow Press Books, Oxford: p. 233-252.

Bates, D., \& Lees, S. 1977, The role of exchange in productive specialization. American Anthropologist, 79: 824-841. doi:10.1525/aa.1977.79.4.02a00040

Baysal, A, \& Wright, K. 2005, Cooking, crafts and curation: Ground-stone artefacts from Catalhoyuk, 1995-1999. In: Excavations at Catalhoyuk, 1995-1999. Volume 5:

Changing Materiality (Hodder, I., Ed.), Monographs of the McDonald Institute for Archaeological Research, University of Cambridge, Cambridge: p. 307-324.

Blackman, M.J., Stein, G.J. \& Vandiver, P. 1993, The standardization hypothesis and ceramic mass production: Technological, compositional, and metric indexes of craft specialization at Tell Leilan, Syria. American Antiquity, 58: 60-79. doi:10.2307/281454

Braun, E. 1990, Basalt bowls of the EB I horizon in the southern Levant. Paléorient, 16: 8796. doi:10.3406/paleo.1990.4521

van den Brink, E.C.M., Rowan, Y.M., \& Braun, E. 1999, Pedestalled basalt bowls of the Chalcolithic: New variations. Israel Exploration Journal, 49: 161-183.

URL: http://www.jstor.org/stable/27926891

Costin, C.L. 2005, Craft production. In: Handbook of Archaeological Methods (Maschner, H.D.G., \& Chippindale, C., Eds.), Altamira Press, New York: p. 1034-1107.

Dubreuil, L., \& Savage, D. 2014, Ground stones: A synthesis of the use-wear approach. Journal of Archaeological Science, 48: 139-153. doi:10.1016/j.jas.2013.06.023

Earle, T.K., \& Ericson, J.E., 1977, Exchange systems in archaeological perspective. In: Exchange Systems in Prehistory (Earle, T.K., \& Ericson, J.E., Eds.), Academic Press, New York: p. 3-12. doi:10.1016/B978-0-12-227650-7.50007-9

Ebeling, J.R., \& Rosenberg, D. 2015, A basalt vessel workshop and its products at Iron Age Hazor, Israel, Journal of Field Archaeology, 40:6, 665-674. doi:10.1080/00934690.2015.1101941

Ebeling, J.R., \& Rowan, Y.M. 2004, The archaeology of the daily grind: Ground stone tools and food production in the southern Levant. Near Eastern Archaeology, 67: 108-117. doi:10.2307/4132366

Eerkens, J.W., \& Bettinger, R.L. 2001, Techniques for assessing standardization in artifact assemblages: Can we scale material variability? American Antiquity, 66(3): 493-504. doi:10.2307/2694247 
Fratt, L., \& Biancaniello, M. 1993, Homol'ovi III ground stone in the raw: A study of the local sandstone used to make ground stone artifacts. Kiva, 58: 371-382. doi:10.1080/00231940.1993.11758216

Gifford, J.C. 1960, The type-variety method of ceramic classification as an indicator of cultural phenomena. American Antiquity, 25: 341-347. doi:10.2307/277517

Gluhak, T.M., \& Rosenberg, D. 2013, Geochemical discrimination of basaltic sources as a tool for provenance analyses of bifacial tools in the southern Levant: First results from the Jezreel Valley, Israel. Journal of Archaeological Science, 40: 1611-1622. doi:10.1016/j.jas.2012.11.003

Gluhak, T.M., Rosenberg, D., \& Ebeling J. 2015. Raw material variability and provenance as archaeological tools: Preliminary results from a geochemical study of the basalt vessel workshop at Iron Age Tel Hazor, Israel. Paper presented at Association for Ground Stone Research $1^{\text {st }}$ Conference, University of Haifa, Israel. July 5-9, 2015.

Greenberg, R. 2014, Introduction to the Levant during the Early Bronze Age. In: The Archaeology of the Levant (Steiner, M.L., \& Killebrew, A.E., Eds.), Oxford University Press, Oxford: p. 425-437. doi:10.1093/oxfordhb/9780199212972.013.019

Greenfield, H.J., Shai, I., \& Maeir, A.M. 2012, Being an “ass”: An Early Bronze Age burial of a donkey from Tell es-Safi/Gath, Israel. Bioarchaeology of the Near East, 6: 21-52.

Greenfield, H.J., Wing, D., \& Maeir, A.M. 2015. LiDAR technology as an analytical tool at Tell es-Safi/Gath, Israel. In: Breaking Barriers: Proceedings of the $46^{\text {th }}$ Annual Chacmool Archaeological Conference, November 7-9, Calgary, AB (Crook, R., Edwards, K., \& Hughes, C., Eds.), University of Calgary, Calgary: p. 76-85.

Grigson, C. 2012, Size matters - Donkeys and horses in the prehistory of the southern Levant. Paléorient, 38: 185-201. doi:10.3406/paleo.2012.5468

Gvirtzman, G., \& Buchbinder, B. 1969, Outcrops of Neogene formation in the central and southern coastal plain, Hashephela and Be'er Sheva regions, Israel. In: Bulletin Vol. 50, Ministry of Development, Geological Survey of Israel, Jerusalem: p. 1-52.

Hamon, C. 2008, Functional analysis of stone grinding and polishing tools from the earliest Neolithic of north-western Europe. Journal of Archaeological Science, 35: 1502-1520. doi:10.1016/j.jas.2007.10.017

Hayden, B. 1987, Traditional metate manufacturing in Guatemala using chipped stone tools. In: Lithic Studies Among the Contemporary Highland Maya (Hayden, B., Ed.), University of Arizona Press, Tuscon: p. 8-119.

Hovers, E. 1996, The groundstone industry. In: Excavations at the City of David IV 1978-85 (de Groot, A., \& Ariel, D., Eds.), Qedem, Jerusalem: p. 171-192.

Katz, J.C. 2012, A preliminary report of the ground stone objects. In: Tell es-Safi/Gath I: The 1996-2005 Seasons (Maeir, A.M., Ed.), Harrassowitz, Wiesbaden: p. 491-500.

Liu, L., Field, J. ,Fullagar, R., Zhao, C., Chen, X., \& Yu, J. 2010, A functional analysis of grinding stones from an early Holocene site at Donghulin, north China. Journal of Archaeological Science, 37: 2630-2639. doi:10.1016/j.jas.2010.05.023

Maeir, A.M. 2012, Tell es-Safi/Gath archaeological project 1996-2010: Introduction, overview, and synopsis of results. In: Tell es-Safi/Gath I: The 1996-2005 Seasons (Maeir, A.M., Ed.), Harrassowitz, Wiesbaden: p. 1-88. 
Maeir, A.M., Shai, I., \& Horwitz, L.K. 2011, Like a lion in cover: A cylinder seal from Early Bronze Age III Tell es-Safi/Gath, Israel. Israel Exploration Journal, 61: 12-31.

Mallory, J.K. 1986, “Workshops” and "specialized production” in the production of Maya chert tools: A response to Shafer and Hester (1983). American Antiquity, 51: 152-158. doi:10.2307/280401

Mallory-Greenough, L.M., \& Greenough, J.D. 2004, Whole rock trace element analyses applied to the regional sourcing of ancient basalt vessels from Egypt and Jordan. Canadian Journal of Earth Science, 41: 699-709. doi:10.1139/e04-013

Masson, M.A. 2005, Trade and exchange. In: Handbook of Archaeological Methods (Maschner, H.D.G., \& Chippindale, C., Eds.), Altamira Press, New York: p. 1138-1178.

Midant-Reynes, B. 2000, The Naqada period (c. 4000-3200 BC). In: The Oxford History of Ancient Egypt (Shaw, I., Ed.), Oxford University Press, New York: p. 41-56.

Milevski, I. 2008, The exchange of ground stone tools and vessels during the Early Bronze Age in the southern Levant. In: New Approaches to Old Stones: Recent Studies of Ground Stone Artifacts (Rowan, Y.M., \& Ebeling, J.R., Eds.), Equinox Publishing Ltd., London: p. 116-129.

Milevski, I. 2011, Early Bronze Age Goods Exchange in the Southern Levant: A Marxist Perspective. Equinox Publishing Ltd., London, 294 p.

de Miroschedji, P. 1999, Yarmuth: The dawn of city-states in southern Canaan. Near Eastern Archaeology, 62: 2-19. doi:10.2307/3210719

de Miroschedji, P. 2003, The Late EBIII Palace B1 at Tel Yarmuth: A descriptive summary. Eretz-Israel, 27: 153-170.

de Miroschedji, P. 2006, At the dawn of history: Socio-political developments in southwestern Canaan in Early Bronze Age III. In: I Will Speak the Riddles of Ancient Times: Archaeological and Historical Studies in Honor of Amihai Mazar on the Occasion of His Sixtieth Birthday (Maeir, A.M., \& de Miroschedji, P., Eds.), Eisenbrauns, Winona Lake: p. 55-78.

de Miroschedji, P. 2009, Rise and collapse in the southern Levant in the Early Bronze Age. Scienze Dell'Antichita: Storia Archeologia Antropologia, 15: 101-129.

Paz, S. 2012, Changing households at the rise of urbanism: The EBI-III transition at Tel Bet Yerah. In: New Perspectives on Household Archaeology (Parker, B.J., \& Foster, C., Eds.), Eisenbrauns, Winona Lake: p. 407-434.

Philip, G., \& Williams-Thorpe, O. 1993, A provenance study of Jordanian basalt vessels of the Chalcolithic and EBI periods. Paléorient, 19: 51-63. doi:10.3406/paleo.1993.4596

Porat, N., \& Seeher, J. 1988. Petrographic analyses of pottery and basalt from Predynastic Maadi. Mitteilungen der Deutschen Archaologischen Instituts, Abteilung Kairo, 44: 215-228.

Rathje, W.L. 1972, Praise the gods and pass the metates: A hypothesis of the development of lowland rainforest civilizations in Mesoamerica. In: Contemporary Archaeology: A Guide to Theory and Contributions (Leone, M.P., Ed.), Southern Illinois Press, Carbondale: p. 365-392. 
Renfrew, C. 1977, Alternative models for exchange and spatial distribution. In: Exchange Systems in Prehistory (Earle, T.K., \& Ericson, J.E., Eds.), Academic Press, New York: p. 71-90. doi:10.1016/B978-0-12-227650-7.50010-9

Rosenberg, D. 2010, Early maceheads in the southern Levant: a "Chalcolithic” hallmark in Neolithic context. Journal of Field Archaeology, 35: 204-216. doi:10.1179/009346910X12707321520512

Rosenberg, D. 2015, The Wadi Rabah slingstones: some new thoughts on flying stones. Poster presented in Association for Ground Stone Research $1^{\text {st }}$ Conference, University of Haifa, Israel. July 5-9, 2015.

Rouse, I. 1960, The classification of artifacts in archaeology. American Antiquity, 25: 313323. doi:10.2307/277514

Rowan, Y.M. 2003, The groundstone assemblage. In: Salvage Excavations at the Early Bronze Age Site of Qiryat Ata (Golani, A., Ed.), IAA Reports, Jerusalem: p. 183-202.

Rowan, Y.M. 2014, Stone artifact assemblage from Tell Jemmeh. In: The Smithsonian Institution Excavation at Tell Jemmeh, Israel, 1970-1990 (Ben-Shlomo, D., \& Van Beek, G.W., Eds.), Smithsonian Institution Scholarly Press, Washington D.C.: p. 917969. doi:10.5479/si.19436661.50

Rowan, Y.M., \& Ebeling, J.R. 2008, Introduction: the potential of ground stone studies. In: New Approaches to Old Stones: Recent Studies of Ground Stone Artifacts (Rowan, Y.M., \& Ebeling, J.R., Eds.), Equinox Publishing Ltd., London: p. 1-15.

Rowan, Y.M., Levy, T.E., Alon, D., \& Goren, Y. 2006. Gilat’s ground stone assemblage: stone fenestrated stands, bowls, palettes and related artifacts. In: Archaeology, Anthropology and Cult: The Sanctuary at Gilat, Israel (Levy, T.E., Ed.), Equinox Publishing Ltd., London: p. 575-684.

Rutter, G.P. 2003, Basaltic-rock procurement systems in the southern Levant: case studies from the Chalcolithic-Early Bronze Age I and the Late Bronze-Iron Ages. Ph.D. dissertation, University of Durham, UK.

Rutter, G.P., \& Philip, G. 2008, Beyond provenance analysis: the movement of basaltic artefacts through a social landscape. In: New Approaches to Old Stones: Recent Studies of Ground Stone Artifacts (Rowan, Y.M., \& Ebeling, J.R., Eds.), Equinox Publishing Ltd., London: p. 343-358.

Savage, S.H. 2011, From Maadi to the Plain of Antioch: what can basalt spindle whorls tell us about overland trade in the Early Bronze Age I Levant. In: Daily Life, Materiality, and Complexity in Early Urban Communities of the Southern Levant (Chesson, M., Eds.), Eisenbrauns, Winona Lake: p. 119-138.

Schneider, J.S. 1996, Quarrying and production of milling, Implements at Antelope Hill, Arizona. Journal of Field Archaeology, 23(3): 299-331. doi:10.1179/009346996791973828

Schneider, J.S., \& LaPorta, P.C. 2008, Geological constraints on ground stone production and consumption in the southern Levant. In: New Approaches to Old Stones: Recent Studies of Ground Stone Artifacts (Rowan, Y.M., \&Ebeling, J.R., Eds.), Equinox Publishing Ltd., London: p. 19-40.

Shafer, H.J., \& Hester, T.R. 1986, Maya stone-tool craft specialization and production at Colha, Belize: reply to Mallory. American Antiquity, 51: 158-166. doi:10.2307/280402 
Shai, I., Greenfield, H.J., Regev, J., Boaretto, E., \& Maeir, A.M. 2014, The Early Bronze Age remains at Tell es-Safi/Gath, Israel: an interim report. Tel Aviv, 41: 20-49. doi:10.1179/0334435514Z.00000000034

Shai, I., Uziel, J. \& Maeir, A.M. 2012, The architecture and stratigraphy of Area E: Strata E1E5. In: Tell es-Safi/Gath I: The 1996-2005 Seasons (Maeir, A.M., Ed.), Harrassowitz, Wiesbaden: p. 221-234.

Shawabekeh, K. 1998, The Geology of the Ma'in Area. Jordanian Geological Mapping Division, Bulltetin 40, Amman.

Silver, M. 2007, Redistribution and markets in the economy of Ancient Mesopotamia: updating Polanyi. Antiguo Oriente, 5: 89-112.

Sneh, A., Bartov, Y., \& Rosensaft, M. 1997, Geological Map of Israel 1:200,000 (Sheet 1). Geological Survey of Israel, Jerusalem.

Sparks, R. 2001, Stone vessel workshops in the Levant: luxury products of a cosmopolitan age. In: The Social Context of Technological Change: Egypt and the Near East, 16501550 BC (Shortland, A.J., Ed.), Oxbow, Oxford: p. 93-112.

Steinitz, G., \& Bartov, Y. 1992, The Miocene-Pleistocene history of the Dead Sea segment of the Rift in light of K-Ar ages of basalts. Israel Journal of Earth-Sciences, 38(2-4); 199208.

Tzin, B., Atrash, W., Golani, A., \& Rosenberg, D. 2015, Standardization of MB IIB grinding technology. Poster presented at Association for Ground Stone Research $1^{\text {st }}$ Conference, University of Haifa, Israel. July 5-9, 2015.

Uziel, J., \& Maeir, A.M. 2005, Scratching the surface at Gath: implications of the Tell esSafi/Gath surface survey. Tel Aviv, 32(1): 50-75. doi:10.1179/tav.2005.2005.1.50

Valado, M.T. 2008, Identifying lightly used polishing stones: experiments and implications. In: New Approaches to Old Stones: Recent Studies of Ground Stone Artifacts (Rowan, Y.M., \& Ebeling, J.R., Eds.), Equinox Publishing Ltd., London: p. 173-181.

VanPool, T.L., \& Leonard, R.D. 2002, Specialized ground stone production in the Casas Grandes region of northern Chihuahua, Mexico. American Antiquity, 67: 710-730. doi:10.2307/1593800

Veenhof, K.R. 1997, “Modern” features in Old Assyrian trade. Journal of the Economic and Social History of the Orient, 40: 336-366. doi:10.1163/1568520972601549

Weinstein, Y. 2000, Spatial and temporal geochemical variability in basin-related volcanism, northern Israel. Journal of African Earth Sciences, 30(4): 865-886. doi:10.1016/S08995362(00)00057-9

Wright, K. 1992, A classification system for ground stone tools from the prehistoric Levant. Paléorient, 18: 53-81. doi:10.3406/paleo.1992.4573

Wright, K. 2008, Craft production and the organization of ground stone technologies. In: New Approaches to Old Stones: Recent Studies of Ground Stone Artifacts (Rowan, Y.M., \& Ebeling, J.R., Eds.), Equinox Publishing Ltd., London: p. 130-143.

Wright, K. 2014, Domestication and inequality? Households, corporate groups and food processing tools at Neolithic Catalhoyuk. Journal of Anthropological Archaeology, 33: 1-33. doi:10.1016/j.jaa.2013.09.007 